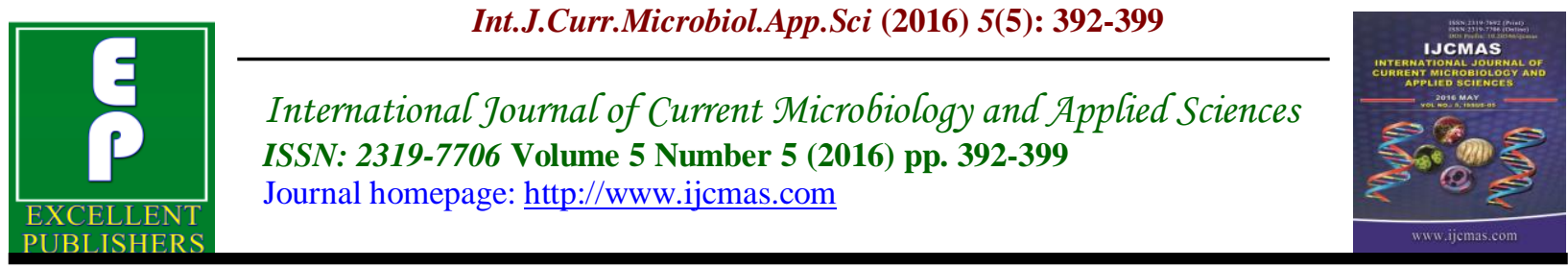

Original Research Article

http://dx.doi.org/10.20546/ijcmas.2016.505.040

\title{
Is Spontaneous Bacterial Peritonitis still Responding to Third Generation Cephalosporins? : A Single Centre Experience
}

\author{
Sherief Abd-Elsalam ${ }^{1 *}$, Hanan Soliman ${ }^{1}$, Walaa Elkhalawany ${ }^{1}$, Haidy Khalil ${ }^{2}$, \\ Samah Soliman ${ }^{1}$, Eslam Ismail ${ }^{1}$ and Loai Mansour ${ }^{1}$ \\ ${ }^{1}$ Tropical Medicine \& Infectious Diseases department, Tanta University \\ Faculty of Medicine, Tanta, Egypt \\ ${ }^{2}$ Microbiology department, Tanta University Faculty of medicine, Tanta, Egypt \\ *Corresponding author
}

\begin{abstract}
A B S T R A C T
Keywords

Liver cirrhosis;

Ascites;

Spontaneous

bacterial

peritonitis;

3rd generation

cephalosporins.

\section{Article Info}

Accepted:

15 April 2016

Available Online:

10 May 2016

The aim of this study was to assess the response of patients with SBP to thirdgeneration cephalosporins in Nile delta. Current international guidelines recommend the use of a third-generation cephalosporin for empirical treatment of SBP. However, reports about antibiotic resistance for third-generation cephalosporins increased dramatically. Which raise the questions about these guidelines and if they are still valid. One hundred patients with liver cirrhosis, ascites and first episode of SBP signed informed consent to participate in this study. They were admitted to Department of Tropical Medicine and Infectious diseases-Tanta University hospital for one week during the period from January to December 2014. The patients were randomly assigned to receive either cefotaxime 2 gm every 12 hours or ceftriaxone 2 gm every 24 hours. Their ascitic fluid samples were re-examined after 48 hours and after 5 days to assess the response to third-generation cephalosporins. On assessment of the response to third-generation cephalosporins after 48 hours, $65 \%$ of patients had satisfactory response (decrease $25 \%$ at least in PMNL count) while $35 \%$ did not achieve a satisfactory response and were shifted to another antibiotic. After 5 days, only 46/65of initial responders achieved complete response. Ceftriaxone had higher response rates than Cefotaxime. However, this difference was non-significant. Based on our study, There is a dramatic decrease in the response rate of SBP to third-generation cephalosporins. This marked decrease in the response should be watched closely as it suggests re-considering of the current guidelines for empiric therapy in SBP.

(Clinical Trials.gov Identifier: NCT02443285).
\end{abstract}

\section{Introduction}

Spontaneous bacterial peritonitis (SBP) is defined as an infection of ascites in the absence of a contiguous source of infection (Tandon et al., 2008). SBP is a common and potentially fatal bacterial infection in patients with cirrhosis and ascites, occurring in 10 to $30 \%$ of patients, with in-hospital mortality rates ranging from 20 to $30 \%$ (Appenrodt et al., 2010; Barreales et al., 2011). 
It is secondary to impaired humoral and cellular immune responses that result in indirect intestinal bacterial translocation into the ascitic fluid (European Association for the Study of the Liver, 2010; Rogers et al., 2010; Soriano et al., 2011).

SBP is also associated with a poor long-term prognosis for patients, as mortality rates can reach 50 to $70 \%$ at 1 year. Early diagnosis and early optimal treatment of these infections with appropriate antibiotics and the prevention of hepatorenal syndrome with albumin are required.Current international guidelines recommend the use of a thirdgeneration cephalosporin as the first choice, or amoxicillin-clavulanate acid or fluoroquinolones as an alternative choice in treatment of SBP. These recommendations are based mainly on the assumption that E. coli would be involved in nearly half of the cases, and the response in clinical trials. The microbial etiology of SBP remains relatively constant. However, reports about antibiotic resistance for third-generation cephalosporins (including cefotaxime and ceftazidime), ciprofloxacin, and ofloxacin increased dramatically, Which raise the question are these clinical trials still valid after a decade or more? Or should we modify our guidelines according to the emerging drug resistance?

So, the aim of our study was to assess the response of patients with spontaneous bacterial peritonitis to two types of thirdgeneration cephalosporins in Nile delta

\section{Methods}

This study was carried out on 100 patients with liver cirrhosis and spontaneous bacterial peritonitis who were admitted in Tanta University hospital, Tropical Medicine Department in the period between January 2014 to December 2014.The patients were randomly assigned by envelop randomization into two equal groups:

Group 1: 50 patients were treated with cefotaxime $2 \mathrm{gm}$ every 12 hoursdaily.

Group 2: 50 patients were treated with ceftriaxone 2 gm every 24 hours.

All patients were subjected to the following: full history taking, thorough clinical examination, urea and creatinine, liver function tests including; bilirubin level, albumin level, and prothrombin time, abdominal Ultra Sound, ascitic fluid sampling, ascitic fluid analyses include cell counts and differential counts, ascitic fluid culture and microbiological testing. Peritoneal fluid sampling was performed utilizing standard and universal precautions of antiseptic technique.

Culture-positive SBP was diagnosed in the presence of ascitic fluid PMNL $\geq$ 250 cells $/ \mathrm{mm} 3$ and positive ascitic fluid culture for a single organism. If culture was positive to more than one organism; case was excluded from the study and another case was randomized to be allocated into this group to keep equal groups. Patients with positive culture and $P M N L<250$ cells/mm3 (Bacteriascites) were also excluded from our study.

The response was assessed after 48 hours by decrease $25 \%$ at least in PMNL count. If patients achieved early response, they continued their drug with same dose then subjected to diagnostic paracentesis at day 5 of therapy. If ascitic sample had PMNL $<250$ cells $/ \mathrm{mm} 3$, it indicated cure of the patient. If $P M N L \geq 250$ it indicated resistance. For those who did not achieve early response at 48 hours, another antibiotic line of therapy was started.

The duration of the study was 12 months. The study was approved by Ethical 
Committee of the Faculty of Medicine, Tanta University. A written consent was taken from all participants in this research. A code number for each patient was used, and kept in a special fileto maintain Patients' privacy during the research. Study was registered at clinicaltrial.gov with Identifier: NCT02443285.

\section{Results and Discussion}

Among 350 cirrhotic patients with ascites examined routinely in the period of the study 100 patients met the inclusion criteria of SBP and were allocated randomly for treatment. Our 100 SBP patients were 54 male and 46 female, among them $42 \%$ had Child score B and 58\% had Child score C, and $14 \%$ were diabetics. Most of our patients presented clinically by one or more of the following as lacking response to diuretics, abdominal pain, abdominal tenderness, hepatic encephalopathy, recent onset hematemesis (within one week). Only 3 patients were completely asymptomatic and were admitted for unrelated conditions ( 2 with painless bleeding per rectum proved to be piles, and one for focal lesion in the liver discovered accidentally in ultrasound examination and was proved to be heamangioma with triphasic CT examination) (table 1). The mean age of our patients was $53.8 \pm 7.5$. At day one, they have ascitic fluid total cell count of 744.2 \pm 605 , and polymorphonuclear leucocytic (PNL) count of 528.9 \pm 499.7 . Demographic and other laboratory data are showed in table 2 . At 48 hours follow up, the mean of total cell count was $163.69 \pm 80.86$, and that of PMNL was $86.05 \pm 67.19$ which were significantly lower than baseline levels. However, only 65 patients achieved satisfactory response with at least $25 \%$ reduction of their initial PNL count. The remaining 35 patients were shifted to alternative lines of antibiotics and re-assessed after another 48 hours for their response. Anyhow, 4 of them died by third day. The data of the remaining 31 patients were no more included in this study.

The 65 patients with initial response continue their therapy with same dose. They were $31 / 50$ patients on cefotaxime and $34 / 50$ on ceftrixone. At day 5 patients were reevaluated for cure $(\mathrm{PMNL}<250$ in ascitic sample), with $46 / 65$ patients get $\mathrm{PMNL}<250$ (22/31 on cefotaxime and $24 / 34$ in ceftriaxone) (fig.1). There was no significant difference between response rates to both types of 3rd generation cephalosporine used after 48 hours or at end of therapy (table $3)$.When our patients were stratified according to satisfactory response after 2 days into satisfactory responders $(n=65)$ and non responders $(n=35)$, no significant difference was found between pre-treatment PNL count of responders and non responders(table 4). However, when those who get early satisfactory response at day 2 were stratified according to persistence of infection at day 5, PMNL count was significantly lower in patients who resolved infection $(n=46)$ at pretreatment and at 2 days of therapy (table5). Among 46 patients who resolved infection 21 had Child score $\mathrm{B}$, and 25 had Child score $\mathrm{C}$.

\section{Statistical Analysis}

The statistical data are reported as the mean $\pm \mathrm{SD}$, median and range as most of data are not normally distributed. Frequencies (number and percentages) were used when appropriate. A comparison of numerical variables between the study groups was performed using Mann-Whitney $U$ test to compare independent samples as the samples were not normally distributed. To compare categorical data, chi square or fisher exact test were performed. For all used tests, P-values less than 0.05 were considered statistically significant. All statistical calculations were performed using 
the computer program SPSS (Statistical Package for the Social Science; SPSS, Chicago, IL, USA) version15 for Microsoft Windows.

\section{Clinical Trials gov Identifier: NCT02443285}

Since 1985 when the famous clinical trial of Felisart et al., (1985) introduced Cefotaxime as an emperical treatment for SBP, mortality rates were reduced from $90 \%$ to around $20 \%$. This marvelous response encouraged the use of cefotaxime and other 3rd generation cephalosporins. Now, most guidelines recommend it as empiric therapy of choice in treatment of SBP. However, this study was performed 3 decades ago. There are many recent reports of evolving resistance to cefotaxime and other thirdgeneration cephalosporins in SBP (Sheikhbahaei et al., 2014; Felisart et al., 1985; Fernández et al., 2012; Angeloni et al., 2008; Novovic et al., 2012).

The most frequent clinical manifestations of
SBP are fever (69\%) and abdominal pain $(59 \%)$. Lower figures were found in our patients but abdominal pain, and fevers were still the most common manifestation in our patients after lacking of response to diuretics. Only 3out of 100 patients were completely asymptomatic. This is lower than data reported by Badawy et al., who reported $18 \%$ of his patients to be asymptomatic. This difference may be due to patient recruitment as our study had no outpatient participants and all of our patients were indicated for hospitalization. SBP is more prevalent in advanced liver disease 18. This was reinforced by our results as $42 \%$ of our patients had Child score B and $58 \%$ had score $\mathrm{C}$ indicating advanced liver disease. However, our results were lower than Badawy et al., who reported child class $\mathrm{C}$ in more than $90 \%$ of his patients, this is because all of our patients had their first attack of SBP rendering more chance for class B patients to be included.

Table.1 Patients' Baseline Characters.

\begin{tabular}{|c|c|c|c|c|}
\hline Parameter & $\begin{array}{r}\text { Cefotaxime } \\
(\mathrm{n}=50)\end{array}$ & $\begin{array}{r}\text { Ceftriaxone } \\
(\mathrm{n}=50)\end{array}$ & Chi & P-value \\
\hline Gender, male $\mathrm{n}(\%)$ & $29(58)$ & $31(62)$ & 0.042 & 0.838 \\
\hline $\begin{array}{l}\text { Child Pugh score } \\
\text {-Child B n (\%) } \\
\text {-Child C n (\%) }\end{array}$ & $\begin{array}{l}23(46) \\
27(54)\end{array}$ & $\begin{array}{l}19(38) \\
31(62)\end{array}$ & 0.369 & 0.543 \\
\hline Diabetes mellitus n (\%) & $8(16)$ & $6(12)$ & 0.003 & 0.773 \\
\hline $\begin{array}{l}\text { Symptoms of SBP } \\
\text { - A symptomatic } \\
\text { - } \text { Fever } \\
\text { - Abdominal pain } \\
\text { - Abdominal tenderness } \\
\text { - } \text { Recent onset hematemesis } \\
\text { - Hepatic encephalopathy } \\
\end{array}$ & $\begin{array}{l}1(2) \\
36(72) \\
26(52) \\
27(54) \\
16(38) \\
9(18) \\
5(10)\end{array}$ & $\begin{array}{l}2(4) \\
34(68) \\
27(54) \\
31(62) \\
12(24) \\
5(10) \\
7(14) \\
\end{array}$ & $\begin{array}{l}0 \\
0.048 \\
0.044 \\
0.369 \\
0.446 \\
0.748 \\
0.95 \\
\end{array}$ & $\begin{array}{l}1 * \\
0.827 \\
0.831 \\
0.543 \\
0.506 \\
0.387 \\
0.758 \\
\end{array}$ \\
\hline
\end{tabular}

*=examined with fisher exact test 
Table.2 Patients' Demographic and Laboratory Data at Base Line

\begin{tabular}{|c|c|c|c|c|}
\hline $\begin{array}{l}\text { Parameter } \\
\text { (mean } \pm \text { SD) } \\
\text { Median (range) }\end{array}$ & $\begin{array}{c}\text { Cefotaxime } \\
(\mathbf{n}=50)\end{array}$ & $\begin{array}{c}\text { Ceftriaxone } \\
(\mathbf{n}=50)\end{array}$ & $\begin{array}{c}\text { P- } \\
\text { value }\end{array}$ & $95 \% \mathrm{CI}$ \\
\hline Age in years & $\begin{array}{c}54.18 \pm 7.09 \\
55(66-40)\end{array}$ & $\begin{array}{c}53.78 \pm 7.52 \\
54(66-41)\end{array}$ & 0.495 & $1.98-3.9$ \\
\hline Serum albumin, $\mathrm{g} / \mathrm{dL}$ & $\begin{array}{c}2.78 \pm 0.38 \\
2.95(3.2-1.8)\end{array}$ & $\begin{array}{c}2.74 \pm 0.32 \\
2.8(3.3-1.9)\end{array}$ & 0.492 & $0.09-0.19$ \\
\hline Total bilirubin $\mathrm{mg} / \mathrm{dL}$ & $\begin{array}{c}2.70 \pm 1.58 \\
2.15(7-0.8)\end{array}$ & $\begin{array}{c}2.65 \pm 1.67 \\
2.05(7-0.8)\end{array}$ & 0.878 & $0.6-0.7$ \\
\hline Serum creatinine, $\mathrm{mg} / \mathrm{Dl}$ & $\begin{array}{c}1.33 \pm 0.55 \\
1.2(3-0.6)\end{array}$ & $\begin{array}{c}1.34 \pm 0.50 \\
1.25(3-0.6)\end{array}$ & 0.924 & $0.22-0.20$ \\
\hline Hemoglobin, g/dL & $\begin{array}{c}9.77 \pm 1.15 \\
9.8(12-7.5)\end{array}$ & $\begin{array}{c}9.49 \pm 1.07 \\
9.4(12-7.5)\end{array}$ & 0.211 & $0.16-0.72$ \\
\hline White blood cells $\left(\times 10^{3}\right)$ & $\begin{array}{l}7.54 \pm 2.98 \\
7.8(15-2.1) \\
\end{array}$ & $\begin{array}{c}7.93 \pm 2.59 \\
8.05(14.9-2.9) \\
\end{array}$ & 0.407 & $149.8-71.81$ \\
\hline Platelets $\left(\times 10^{3}\right)$ & $\begin{array}{c}98.04 \pm 60.06 \\
90.5(336-39)\end{array}$ & $\begin{array}{l}98.34 \pm 59.15 \\
90(336-39)\end{array}$ & 0.980 & $23.96-23.36$ \\
\hline $\begin{array}{l}\text { Total protein in ascitic } \\
\text { fluid }(\mathrm{g} / \mathrm{dL})\end{array}$ & $\begin{array}{c}1.806 \pm 0.78 \\
1.9(3.6-0.3) \\
\end{array}$ & $\begin{array}{c}1.848+0.85 \\
1.9(3.6-0.3) \\
\end{array}$ & 0.797 & $0.37-0.28$ \\
\hline $\begin{array}{l}\text { Total WBC count in } \\
\text { ascitic fluid }\left(\text { cells } / \mathrm{mm}^{3}\right)\end{array}$ & $\begin{array}{c}867.76 \pm 876.02 \\
527.5(9800-275) \\
\end{array}$ & $\begin{array}{c}734.26 \pm 604 \\
505(2800-280) \\
\end{array}$ & 0.377 & $165.12-432.12$ \\
\hline $\begin{array}{l}\text { PMN in ascitic fluid } \\
\left(\text { cells } / \mathrm{mm}^{3}\right)\end{array}$ & $\begin{array}{c}614.1+633.7 \\
350(2550-252)\end{array}$ & $\begin{array}{c}534.2+498.7 \\
344(2520-250)\end{array}$ & 0.595 & $242.47-420.95$ \\
\hline
\end{tabular}

PMN; polymorphonuclear leukocytes, WBC; white blood cell.

Table.3 Rates of response to 3rd generation cephalosporins in studied groups

\begin{tabular}{|l|r|r|r|r|}
\hline Parameter & $\begin{array}{r}\text { Cefotaxime } \\
(\mathrm{n}=50)\end{array}$ & $\begin{array}{r}\text { Ceftriaxone } \\
(\mathrm{n}=50)\end{array}$ & Chi & P-value \\
\hline $\begin{array}{l}\text { satisfactory response } \\
\text { after 48 hours [no. }(\%)]\end{array}$ & $31(62 \%)$ & $34(68 \%)$ & 0.176 & 0.675 \\
\hline $\begin{array}{l}\text { complete resolution of infection } \\
\text { after 5 days [no. }(\%) \text { ] }\end{array}$ & $22(44 \%)$ & $24(48 \%)$ & 0.04 & 0.841 \\
\hline
\end{tabular}

Satisfactory response $=$ decrease $25 \%$ at least in PMNL count

Complete resolution of infection $=$ ascetic PMNL count less than $250 / \mathrm{mm} 3$

Table.4 Comparing ascetic PNL count in all patients pretreatment and at day 2

\begin{tabular}{|l|c|c|c|c|}
\hline $\begin{array}{l}\text { PNL }\left(\text { cell } / \mathrm{mm}^{3}\right) \\
(\text { mean } \pm \text { SD) } \\
\text { Median (range) }\end{array}$ & $\begin{array}{c}\text { satisfactory response } \\
(\mathrm{n}=65)\end{array}$ & $\begin{array}{c}\text { Non responders } \\
(\mathrm{n}=35)\end{array}$ & $\mathrm{t}$ & P-value \\
\hline Pre treatment & $541.6 \pm 542.8$ & $634.6 \pm \mathbf{6 1 7 . 6}$ & 0.778 & 0.438 \\
& $330(2550-250)$ & $404(2500-252)$ & & \\
\hline after 48 hours & $166.5 \pm 199.9$ & $924 \pm 837.1$ & 6.964 & $<0.0001$ \\
& $100(960-6)$ & $680(4000-300)$ & & \\
\hline
\end{tabular}


Table.5 Comparing ascetic PNL count in patients who got satisfactory response at day 2

\begin{tabular}{|l|c|c|c|c|}
\hline $\begin{array}{l}\text { PNL }\left(\text { cell } / \mathrm{mm}^{3}\right) \\
(\mathbf{m e a n} \pm \mathbf{S D})\end{array}$ & $\begin{array}{c}\text { Resolved infection } \\
\text { Median }(\mathrm{n}=46)\end{array}$ & $\begin{array}{c}\text { persistent infection } \\
(\mathrm{n}=19)\end{array}$ & $\mathrm{t})$ & P-value \\
\hline Pre treatment & $428.5 \pm \mathbf{3 9 5 . 7}$ & $815.5 \pm \mathbf{7 3 7 . 8}$ & 2.744 & 0.008 \\
& $310(2520-250)$ & $490(2550-280)$ & & \\
\hline after 48 hours & $83.3 \pm \mathbf{4 9 . 9}$ & $368.1 \pm \mathbf{2 7 4 . 5}$ & 6.841 & $<0.0001$ \\
& $74(233-0)$ & $250(960-60)$ & & \\
\hline After 5 days & $58.7 \pm \mathbf{3 7 . 1}$ & $642 \pm \mathbf{5 9 3 . 4}$ & 6.711 & $<0.0001$ \\
& $55(180-4)$ & $360(2400-251)$ & & \\
\hline
\end{tabular}

Fig.1 flow diagram showing the progress of parallel groups through the phases of the study

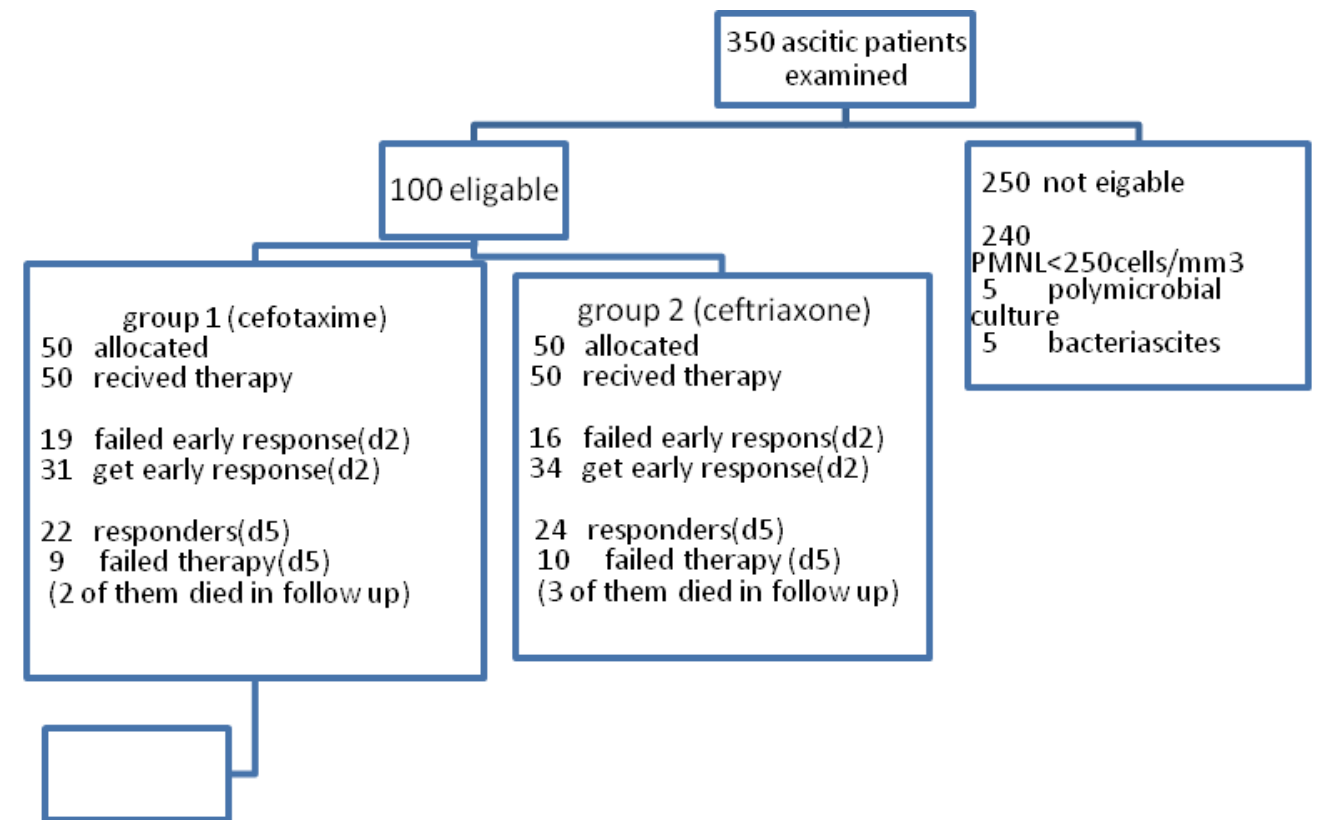

In our study cephalosporins satisfactory response after 2 days was achieved in $65 \%$ of cases, and after complete course only 46/65 resolved their infection. This was far from results reported by Ariza et al., (Paul et al., 2015) who reported third-generation cephalosporin (ceftriaxone) resistance to occur in $21.5 \%$, Badawy et al., who reported $19 \%$ resistance to cefotaxime and Chaulk et al., who reported that $19 \%$ (15 of 77) were resistant to third-generation cephalosporins and Kim et al., who reported in his work cefotaxime resistance to occur in $8.1 \%$ of patients with hepatitis B.

Nevertheless, SBP occurs due to bacterial translocation in patients with advanced cirrhosis (Sun et al., 2010). Third-generation cephalosporins alone covered only one third of the infectious agents isolated from SBP, and the two alternative choices (amoxicilline-clavulanate and fluoroquinolones) did not sufficiently increase the antimicrobial coverage. In a 
recent study, the overall antibiotic coverage was $57 \%$ for cephalosporins, $73 \%$ for piperacillin-tazobactam, and $72 \%$ for meropenem13. Similar results were obtained in india by Bhat et al. (2013) who showed low response rate to 3rd generation cephalosporins in patients with SBP, Yakar et al., who revealed that cefotaxime response rate is $44.6 \%$, Cheongs et al., (2009) who showed that cephalosporin resistance rate was $41 \%$ and Umgelter et al., who revealed that rate of cefotaxime resistance was $33.3 \%$. In our patients, despite more patients responded to ceftrixone than cefotaxime, the difference was not significant. This was in agreement with Sheikhbahaei et al., who stated that resistance to cefotaxime was $62.5 \%$ and ceftriaxone $58.5 \%$.

Since a switch to another antibiotic was necessary to achieve resolution of infection in $56 \%$ of our cases we think 3 rd generation cephalosporins is no more the best first empiric choice in SBP.

In conclusion, Only $65 \%$ of SBP patients who had their first episode got satisfactory response after 48 hours and only $46 \%$ resolved their infection after 5 days. Results were equal for cefotaxime \& ceftriaxone. There is urgent need for clinical trials on alternative antibiotics as the current guidelines for first line empiric therapy in SBP should be re-considered.

\section{References}

Angeloni, S., Leboffe, C., Parente, A., et al. 2008. Efficacy of current guidelines for the treatment of spontaneous bacterial peritonitis in the clinical practice. World. J. Gastroenterol., 7: 14(17): 2757-2762.

Appenrodt, B., Lehmann, L.E., Thyssen, L., et al. 2010. Is detection of bacterial DNA in ascitic fluid of clinical relevance? Eur.
J. Gastroenterol. Hepatol., 22: 14871494.

Ariza, X., Castellote, J., Lora-Tamayo, J., et al. 2012. Risk factors for resistance to ceftriaxone and its impact on mortality in community, healthcare and nosocomial spontaneous bacterial peritonitis. $J$. Hepatol., 56(4): 825-32.

Badawy, A.A., Zaher, T.I., Sharaf, S.M., et al. 2013. Effect of alternative antibiotics in treatment of cefotaxime resistant spontaneous bacterial peritonitis. World. J. Gastroenterol., 28: 19(8): 12711277.

Barreales, M., Fernandez, I. 2011. Spontaneous bacterial peritonitis. Rev. Esp. Enferm. Dig., 103: 255-263.

Bhat, G., Vandana, K.E., Bhatia, S., et al. 2013. Spontaneous ascitic fluid infection in liver cirrhosis: bacteriological profile and response toantibiotic therapy. Indian J. Gastroenterol., 32(5): 297-301.

Chaulk, J., Carbonneau, M., Qamar, H., et al. 2014. Third-generation cephalosporinresistant spontaneous bacterial peritonitis: A single-centre experience summary of existing studies. Can. J. Gastroenterol. Hepatol., 28(2): 83-88.

Cheong, H.S., Kang, C.I., Lee, J.A., et al. 2009. Clinical significance and outcome of nosocomial acquisition of spontaneous bacterial peritonitis in patients with liver cirrhosis. Clin. Infect. Dis., 48(9): 12306.

European Association for the Study of the Liver. EASL. 2010. clinical practice guidelines on the management of ascites, spontaneous bacterial peritonitis and hepatorenal syndrome in cirrhosis. $J$. Hepatol., 53: 397-417.

Felisart, J., Rimola, A., Arroyo, V,. et al. 1985. Cefotaxime is more effective than is ampicillin-tobramycin in cirrhotics with severe infections. Hepatol., 5: 457462.

Fernández, J., Acevedo, J., Castro, M., et al. 2012. Prevalence and risk factors of infections by multiresistant bacteria in 
cirrhosis: A prospective study. Hepatol., 55: 1551-61.

Kim, S.U., Chon, Y.E., Lee, C.K,. et al. 2012. Spontaneous Bacterial Peritonitis in Patients with Hepatitis B Virus-Related Liver Cirrhosis: Community-Acquired versus Nosocomial. Yonsei Med. J., 53(2): 328-336.

Levison, M.E., Bush, L.M. 2005. Peritonitis and intraperitoneal abcesses. In: Mandell GL, Bennett JE, Dolin R, editors. Principles and Practice of Infectious Diseases. 6th ed. Philadelphia: Elsevier; 2005. pp. 927-951.

Novovic, S., Semb, S., Olsen, H., et al. 2012. First-line treatment with cephalosporins in spontaneous bacterial peritonitis provides poor antibiotic coverage. Scand. J. Gastroenterol., 47: 212-216.

Paul, k., Kaur, J., Kazal, H.L. 2015. To Study the Incidence, Predictive Factors and Clinical Outcome of Spontaneous Bacterial Peritonitis in Patients of Cirrhosis with Ascites. J.Clin. Diagn. Res., 9(7): OC09-OC12.

Piroth, L., Pechinot, A., Minello, A., et al. 2009. Bacterialepidemiology and antimicrobial resistance in ascetic fluid: a 2-year retrospective study. Scand. J. Infect. Dis., 41: 847-851.

Rogers, G.B., Russell, L.E., Preston, P.G., et al. 2010. Characterization of bacteria in ascites-reporting the potential of culture-independent, molecular analysis. Eur. J. Clin. Microbiol. Infect. Dis., 29: 533-541.

Sheikhbahaei, S., Abdollahi, A., HafeziNejad, N.H., et al. 2014. Patterns of Antimicrobial Resistance in the
Causative Organisms of Spontaneous Bacterial Peritonitis: A Single Centre, Six-Year Experience of 1981 Samples. Int. J. Hepatol., 917856.

Soriano, G., Esparcia, O., Montemayor, M., et al. 2011. Bacterial DNA in the diagnosis of spontaneous bacterial peritonitis. Aliment. Pharmacol. Ther., 33: 275-284.

Sort, P., Navasa, M., Arroyo, V., et al. 1999. Effect of intravenous albumin on renal impairment and mortality in patients with cirrhosis and spontaneous bacterial peritonitis. N. Engl. J. Med., 341: 403409.

Sun, L., Zhang, J.V., Zhao, J., et al. 2010. Changes in the profiles of bacteria causing spontaneous bacterial peritonitis: A recent twelve-year study. Afr. $J$. Microbiol. Res., 4: 527.

Tandon, P., Garcia-Tsao, G. 2008. Bacterial infections, sepsis, and multiorgan failure in cirrhosis. Semin. Liver Dis., 28: 26-42.

Umgelter, A., Reindl, W., Miedaner, M., et al. 2009. Failure of Current Antibiotic First-Line Regimens and Mortality in Hospitalized Patients with Spontaneous Bacerial Peritonitis. Infect., 37(1): 2-8.

Wiest, R., Krag, A., Gerbes, A. 2012. Spontaneous bacterial peritonitis: recent guidelines and beyond. Gut., 61: 297310.

Yakar, T., Güçlü, M., Serin, E., et al. 2010. A Recent Evaluation of Empirical Cephalosporin Treatment and Antibiotic Resistance of Changing Bacterial Profiles in Spontaneous Bacterial Peritonitis. Dig. Dis. Sci., 55(4): 11491154.

\section{How to cite this article:}

Sherief Abd-Elsalam, Hanan Soliman, Walaa Elkhalawany, Haidy Khalil, Samah Soliman, Eslam Ismail and Loai Mansour. 2016. Is Spontaneous Bacterial Peritonitis still Responding to Third Generation Cephalosporins? : A Single Centre Experience. Int.J.Curr.Microbiol. App.Sci.5(5): 392-399. doi: http://dx.doi.org/10.20546/ijcmas.2016.505.040 